\title{
Biological Control of Pathogens Causing Root Rot Complex in Field Pea Using Clonostachys rosea Strain ACM941
}

\author{
Allen G. Xue \\ Eastern Cereal and Oilseed Research Centre, Agriculture and Agri-Food Canada, K. W. Neatby Building, 960 Carling Avenue, Ottawa, \\ Ontario, Canada K1A 0C6. \\ Accepted for publication 7 October 2002.
}

\begin{abstract}
Xue, A. G. 2003. Biological control of pathogens causing root rot complex in field pea using Clonostachys rosea strain ACM941. Phytopathology 93:329-335.

Pea root rot complex (PRRC), caused by Alternaria alternata, Aphanomyces euteiches, Fusarium oxysporum f. sp. pisi, F. solani f. sp. pisi, Mycosphaerella pinodes, Pythium spp., Rhizoctonia solani, and Sclerotinia sclerotiorum, is a major yield-limiting factor for field pea production in Canada. A strain of Clonostachys rosea (syn. Gliocladium roseum), ACM941 (ATCC 74447), was identified as a mycoparasite against these pathogens. When grown near the pathogen, ACM941 often was stimulated to produce lateral branches that grew directly toward the pathogen mycelium, typically entwining around the pathogen mycelium. When applied to the seed, ACM941 propagated in the rhizosphere and colonized the seed coat, hypocotyl, and roots as the plant developed and grew. ACM941 significantly reduced the recovery of all fungal pathogens from infected seed, increased in vitro seed germination by $44 \%$ and
\end{abstract}

ABSTRACT

Field pea (Pisum sativum L.) is the fourth major crop by acreage of production after wheat, canola, and barley in Canada. There were approximately 1.3 million ha of field pea grown in 2000 , estimated at a total farm value of over $\$ 500$ million (26). Field pea production area is expected to increase to more than 2 million ha by 2005. As production increases and the crop is grown with increasing frequency in the same fields, there has been a greater problem with soilborne and stubbleborne diseases and the ascochyta complex of both the foliage and root $(14,25,38,39)$. These diseases, commonly referred to in Canada as the pea root rot complex (PRRC), are caused by single or combinations of pathogens, including Alternaria alternata, Aphanomyces euteiches, Fusarium oxysporum f. sp. pisi, F. solani f. sp. pisi, Mycosphaerella pinodes, Pythium spp., Rhizoctonia solani, and Sclerotinia sclerotiorum $(29,31)$. The pathogens individually or synergistically cause symptoms such as seed decay, root rot, foot rot, seedling blight, and wilt. The incidence of PRRC varies with year and location, depending on climate, rotation, and cultural practices $(25,29,32)$. Yield losses have been estimated at more than $70 \%$ in years when the disease is severe (11,31). PRRC combined with the ascochyta complex have significantly reduced pea production in Ontario and the Red River Region of Manitoba, where field pea is traditionally grown. A conservative $10 \%$ yield reduction due to PRRC would result in an annual loss of over $\$ 50$ million. As field pea becomes increasingly important, efforts should focus on more effective means of controlling PRRC in Canada and around the world.

Corresponding author: A. G. Xue; E-mail address: axue@agr.gc.ca

Publication no. P-2002-1223-01R

(c) 2003 The American Phytopathological Society seedling emergence by $22 \%$, and reduced root rot severity by $76 \%$. The effects were similar to those of thiram fungicide, which increased germination and emergence by 33 and $29 \%$, respectively, and reduced root rot severity by $65 \%$. When soil was inoculated with selected PRRC pathogens in a controlled environment, seed treatment with ACM941 significantly increased emergence by $26,38,28,13$, and $21 \%$ for $F$. oxysporum f. sp. pisi, F. solani f. sp. pisi, M. pinodes, $R$. solani, and $S$. sclerotiorum, respectively. Under field conditions from 1995 to 1997, ACM941 increased emergence by $17,23,22,13$, and $18 \%$ and yield by $15,6,28,6$, and $19 \%$ for the five respective pathogens. The seed treatment effects of ACM941 on these PRRC pathogens were greater or statistically equivalent to those achieved with thiram. Results of this study suggest that ACM941 is an effective bioagent in controlling PRRC and is an alternative to existing chemical products.

Additional keywords: bioagent, mycoparasitism, Pisum sativum, rhizosphere, seed treatment.

Field pea cultivars resistant to PRRC are not yet available in Canada. Cultural practices to reduce soil compaction, such as crop rotation and tillage, have limited effect, but are often unsatisfactory and not feasible, partly due to the wide adoption of no-till systems $(1,30,32)$. For decades, fungicide seed treatments have been the only means to combat PRRC. However, fungicide seed treatment is not desirable for disease control due to some adverse effects on the environment and ecosystem, such as harm to nontarget organisms, animals, and plants; residues in soil; and contamination of the water and food chains. Fungicides also may induce pathogen resistance, making their effects variable and short lived (6). In addition, fungicides are expensive in comparison with the relatively low commodity price of field pea. Hence, there is a need for an improved PRRC management system with reduced fungicide use.

Biological control of plant pathogens by microorganisms has been considered a more natural and environmentally acceptable alternative to the existing chemical treatment methods $(2,6)$. Accordingly, it is desirable to identify a microorganism that displays antagonistic effects against target pathogens and is capable of survival and propagation in target locations. Several fungi and bacteria have been reported to have antagonistic effects to PRRC pathogens. Specifically, Windels and Kommedahl (33) reported the potential use of Penicillium oxalicum as a seed protectant against seedling blight of pea. Harman et al. (8) and Nelson et al. (18) reported the use of Trichoderma hamatum for the control of Pythium seed rot and Rhizoctonia root rot in pea. Parke et al. (21) and $\mathrm{Xi}$ et al. (34) noted that Pseudomonas cepacia and $P$. fluorescens were effective against Pythium damping-off and Aphanomyces root rot when applied to pea seed. Hwang and Chakravarty $(9,10)$ reported findings of Bacillus subtilis and Gliocladium virens (syn. Trichoderma virens) as bioagents against 
Rhizoctonia root rot when employed with a fungicide. Oyarzun et al. (19) further reported findings of the biological control of pea root rot caused by $F$. solani, with two nonpathogenic $F$. oxysporum isolates. Steinmetz and Schonbeck (27) reported the horticultural use of conifer bark amended with T. harzianum or G. roseum in controlling pre-emergence damping-off of pea caused by Pythium ultimum, and noted that pretreatment with a nutrient solution was required with the $G$. roseum-containing bark for a significant effect against the pathogen. These bioagents were effective against only one or two of the PRRC pathogens at levels no better than the chemical checks; therefore, commercial application of these organisms has not been pursued.

Previous research demonstrated that a strain of Clonostachys rosea (Link.:Fr.) Schroers, Samuels, Serfert and Gams (syn. G. roseum Bainier), ACM941 (American Type Culture Collection [ATCC] 74447), was an effective bioagent against seedborne $M$. pinodes (36). When used as a seed treatment, ACM941 improved emergence and plant health by reducing root rot severity. Further efforts to characterize the morphological and genetic composition of ACM941 revealed an unique colony morphology and DNA fingerprints differing from other known strains of $C$. rosea $(35,37)$. The objectives of the present study were to examine the mycoparasitic activities of ACM941 against PRRC pathogens, the proliferation of the bioagent in the pea rhizosphere after seed application, and the efficacy of the microbial seed treatment in the control of seedborne and soilborne PRRC pathogens compared with commercial fungicides.

\section{MATERIALS AND METHODS}

Microorganisms and culture conditions. Pure cultures of $A$. alternata, A. euteiches, $F$. oxysporum f. sp. pisi, F. solani f. sp. pisi, $M$. pinodes, $P$. aphanidermatum, $R$. solani, and $S$. sclerotior$u m$ were used in various experiments in this study. These pathogens were isolated from naturally infected pea plants in 1997 and are major causal agents of the PRRC. A. euteiches and P. aphanidermatum were grown on corn meal agar (CMA) and the other pathogens on potato dextrose agar (PDA). Cultures of pathogens were stored at $4^{\circ} \mathrm{C}$ and subcultured every 6 months.

C. rosea strain ACM941 used in this study was recovered from a pea plant in 1994 (36). The fungus was freeze dried and stored at $4^{\circ} \mathrm{C}$ in ampoules until required. ACM941 was deposited with the ATCC in 1998 and designated ATCC Accession No. 74447.

Mycoparasitic activities. Hyphal interactions between ACM941 and the pathogens were examined with paired growths of colonies on PDA in 9-cm-diameter petri dishes. The medium was inoculated with a 5-mm-diameter agar disk of both ACM941 and the pathogen cut from the growing edge of 10-day-old cultures on PDA. A strip of cellophane membrane (Sigma-Aldrich Canada Ltd., Oakville, Ontario), cut to 20 by $20 \mathrm{~mm}$, was autoclaved and placed between the bioagent and pathogen in each dish. Dual cultures were incubated at $20^{\circ} \mathrm{C}$ under a 12 -h light-dark cycle. Mycelium intersections and the subsequent overlap of hyphae of both ACM941 and the pathogen began to form after 2 to 3 days. After 4 to 5 days of incubation, mycoparasitic activities were observed with a light microscope (Nikon Canada Inc., Mississauga, Ontario) by removing the cellophane membrane strip from the media, placing it on a microscope slide, and staining it with $0.2 \%$ Trypan blue to aid in the visibility of the mycelia. Mycoparasitic manifestations were photographed using a Nikon camera with 160 Tungsten positive film (Kodak Canada, Toronto, Ontario) at $\times 400$ magnification. There were six replicate dishes for each ACM941pathogen combination and the experiment was repeated twice with similar results.

Seed treatments. Seed were treated with a spore suspension of ACM941 at $10^{7}$ spores per $\mathrm{ml}$ and $5.0 \mathrm{ml}$ per $\mathrm{kg}$ of seed. The suspension was prepared by washing a 4-week-old culture on PDA. Effects of the ACM941 seed treatment were compared with those of Thiram 75WP fungicide (75\% thiram; Uniroyal Chemical Ltd., Elmira, Ontario) at $1.0 \mathrm{~g}$ a.i. per $\mathrm{kg}$ of seed. Thiram was the only seed treatment fungicide recommended for field pea in Canada at the time of these experiments. Nontreated seed were used as controls. Seed were treated in 500-ml Erlenmeyer flasks and were vigorously shaken after the addition of the treatments to ensure uniform seed coverage. Treated seed were air dried before planting.

Growth room and field experiments. For all seed treatment experiments in the growth room, unless specified otherwise, treated seed were planted into wooden planting flats $(35.5$ by 47.0 by $9.0 \mathrm{~cm})$ containing a soil mixture of 2:1:1 ( $\mathrm{vol} / \mathrm{vol} / \mathrm{vol})$ of loam soil, perlite, and peat moss. Each treatment consisted of 100 seeds per flat, with four replicates. Planted flats were placed in a growth room at $20^{\circ} \mathrm{C}$, with a 14 -h photoperiod at $350 \mu \mathrm{mol} \mathrm{m}^{-2} \mathrm{~s}^{-1}$ light intensity. Emergence and root rot severity were assessed 7 and 14 days after planting, respectively. Root rot severity was rated using the 0 to 9 scale described by Xue (36).

Field experiments were conducted at the Morden Research Centre (MRC), Agriculture and Agri-Food Canada, Morden, Manitoba, from 1995 to 1997, and at both MRC and Burdick Farm near Morden in 2000. In 1995 and 1996, the experiments were on a clay loam soil and in 1997 on sandy loam soil. In 2000, the experiments at the MRC were on a clay loam soil and at Burdick Farm on a sandy loam soil. Plots consisted of four rows, each $3.0 \mathrm{~m}$ long and $30 \mathrm{~cm}$ apart, and were spaced $1.2 \mathrm{~m}$ apart. Plots were seeded between 8 and 17 May each year, at a density of 75 seeds $\mathrm{m}^{-2}$. Standard management practices for Manitoba were followed for weed control and crop fertilization. Seedling emergence was counted for each plot 3 to 4 weeks after seeding. Plants were harvested at maturity and yield was determined after seeds were air dried to $13 \%$ moisture content.

Growth of ACM941 in plant rhizosphere. Experiments were conducted using field pea cv. Radley in the growth room and cv. Profi in the field at the MRC and Burdick Farm in 2000. In the growth room, seed treated with ACM941 and nontreated seed were planted $2.5 \mathrm{~cm}$ deep in coarse vermiculite in a $15-\mathrm{cm}$ plastic pot. Seeded pots were watered from the bottom at seeding time until the vermiculite was saturated, then watered as required. Ten seedlings from each of the ACM941-treated and nontreated seed were removed from their respective pots at $3,7,17,28$, and 35 days after seeding. In the field, four plants were randomly selected from each plot at 4,8 , and 12 weeks after seeding, when plants were at the third node, early flowering, and maturity stages, respectively. Experiments were arranged in a completely randomized block design with 10 replicate pots per treatment at each observation in the growth room and 4 replicate plots at each site in the field. Plant parts to be examined if present on the day of observation were seed coat, primary root, hypocotyl or lower stem ( 0 to $3 \mathrm{~cm}$ above seed), and secondary roots.

To estimate the population of ACM941 in the rhizosphere, the parts from each plant were placed in separate $25-\mathrm{ml}$ sterile glass test tubes containing $10 \mathrm{ml}$ of $0.1 \%$ Tween 20 solution, and covered with a metal cap. This initial wash was vortexed for $30 \mathrm{~s}$ at medium speed. Four serial dilutions for each plant part were completed by adding $1 \mathrm{ml}$ of plant solution to $9 \mathrm{ml}$ of $0.1 \%$ Tween 20. The four dilutions from each plant part were plated out using $0.2 \mathrm{ml}$ in each of three replicate dishes containing the Gliocladium selective medium (20). Inoculated dishes were incubated at $20^{\circ} \mathrm{C}$ in the dark and colonies were counted 6 days postinoculation and reassessed after 8 days. The mean number of CFU was calculated for each plant part based on 10 plants per treatment in the growth room and 4 plants from each of the four replicate plots of each treatment in the field.

Effects on seedborne fungal pathogens. The effects of ACM941 seed treatment on seedborne fungal pathogens were examined using the visibly poor seeds of field pea cvs. AC Tamor and Radley harvested from naturally infected plants at Morden, 
Manitoba in 1994 (36). Experiments to determine the seed treatment effect on recovery of fungal pathogens were conducted in the laboratory; whereas experiments on emergence and root rot severity in seedlings developing from the visibly poor seed were done in the growth room. The effects were compared with those of thiram fungicide over nontreated seeds. In laboratory experiments, five seeds of each treatment were placed on PDA amended with streptomycin sulfate at $20 \mathrm{ppm}$ in each of 27 petri dishes, and placed under fluorescent and long-wave ultraviolet lamps (14-h photoperiod) at 22 to $25^{\circ} \mathrm{C}$ for 14 days. Fungi recovered from the seed were identified microscopically. In growth room experiments, seeds were planted 1, 3, 7, 14, 28, and 42 days after treatment, in order to further examine the ability of ACM941 to survive on the seed. Treated seed were stored at $15^{\circ} \mathrm{C}$ between plantings. Experiments were arranged in a completely randomized block design.

Effects on soilborne fungal pathogens. ACM941 was evaluated against five PRRC pathogens, including $F$. oxysporum f. sp. pisi, F. solani f. sp. pisi, M. pinodes, $R$. solani, and S. sclerotiorum, in comparison with thiram fungicide in the growth room and field from 1995 to 1997 . AC Tamor was used in the growth room experiments and AC Tamor and Radley in the field. To prepare inocula, autoclaved wheat grain was infested separately with each pathogen, incubated at $20^{\circ} \mathrm{C}$ for 3 to 4 weeks, and air dried.

In the growth room experiments, the soil mixture used was pasteurized and separately mixed at $5 \%(\mathrm{vol} / \mathrm{vol})$ with the wheat kernel inoculum. The infested soil was placed in containers, watered lightly, covered with transparent plastic sheeting to retain moisture, and incubated at $20^{\circ} \mathrm{C}$ for 3 days before planting. In the field experiments, the inocula were applied to the soil by mixing the infected wheat kernels with pea seeds before seeding and seeded simultaneously at $25 \mathrm{~g}$ per row in 1995 and $10 \mathrm{~g}$ per row in
1996 and 1997. Experiments were arranged in a completely randomized block design for each pathogen in the growth room and in a split-plot design with treatments in the main plots, cultivars in the subplots, with four replicates per treatment in the field.

Statistical analyses. Data were analyzed by analysis of variance and treatment means were separated by the least significant difference (LSD) test at a probability level of 0.05. Analyses were performed using the Statistical Analysis System for personal computers (SAS Institute, Cary, NC; 5).

\section{RESULTS}

Mycoparasitic activities. Growth of ACM941 was observed on the mycelium of all eight fungal pathogens tested (Fig. 1A to $\mathrm{H}$ ). Entwining around the mycelium was a characteristic response of ACM941 to the pathogens after intersection. When growing near the pathogen hyphae, ACM941 often was stimulated to produce lateral branches that were oriented toward the pathogen mycelium (Fig. 1E and G). Penetration and internal growth of hyphae was observed only on A. alternata (Fig. 1A). The further growth of ACM941 into the encompassed mycelium of the other fungi was not found. After the intersection, the pathogen mycelia appeared to stop growing (Fig. 1B and F). ACM941 grew up to the colonies of the pathogens. There was no zone of inhibition formed between ACM941 and the pathogen colonies, or over-growth of the pathogens on the bioagent.

Proliferation of ACM941 in the rhizosphere. ACM941 was recovered from all plant parts assessed in the growth room and field. In the growth room on seed coat, the bioagent increased from a density of approximately 1,000 spores applied per seed by 4-, 1,700-, 4,100-, 6,100-, and 11,000-fold at 3, 7, 17, 28, and 35 days after planting, respectively (Table 1). ACM941 was re-

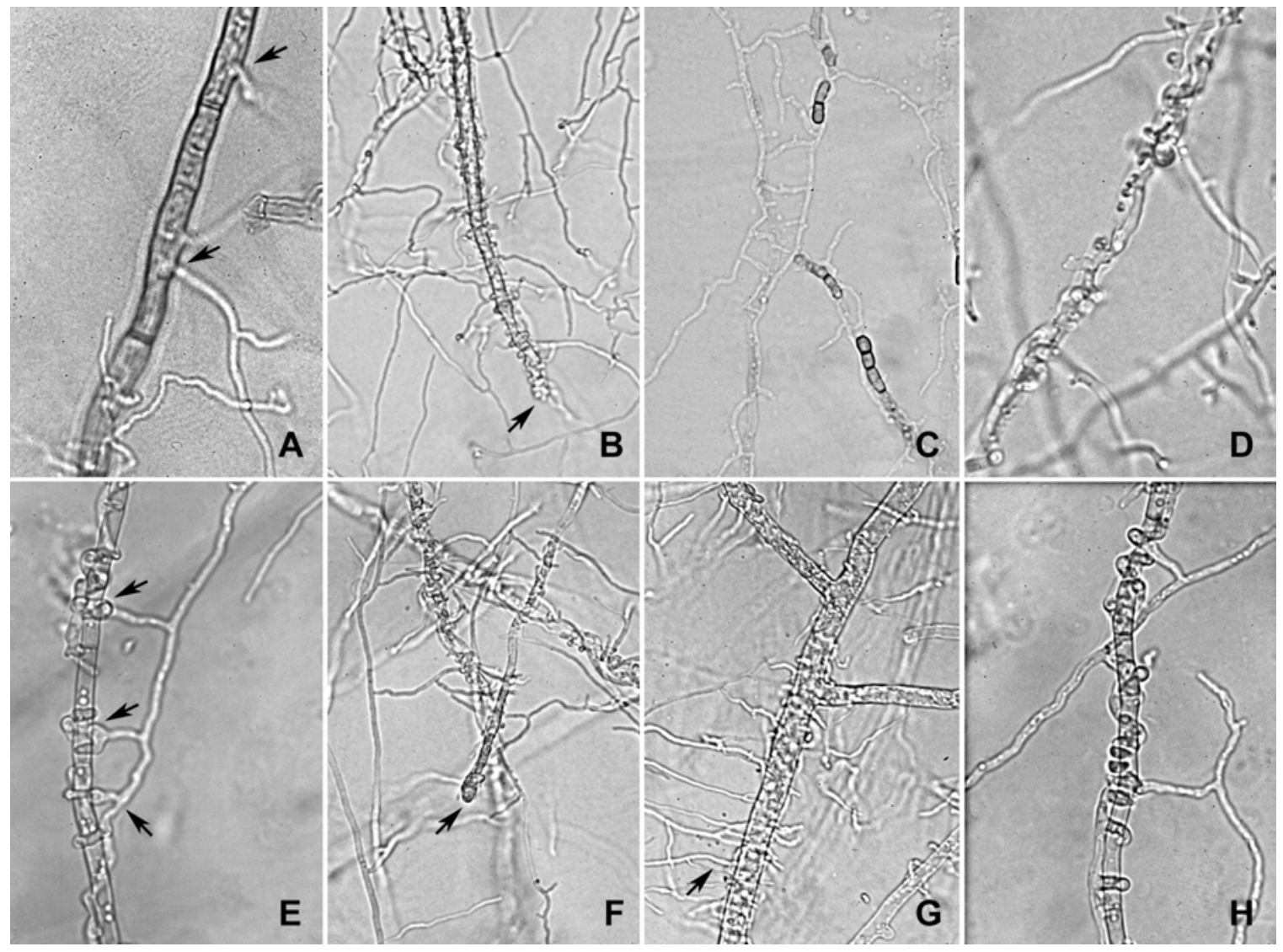

Fig. 1. Mycoparasitism of Clonostachys rosea strain ACM941 against A, Alternaria alternata, B, Aphanomyces euteiches, C, Fusarium oxysporum f. sp. pisi, D, F. solani f. sp. pisi, E, Mycosphaerella pinodes, F, Pythium aphanidermatum, G, Rhizoctonia solani, and $\mathbf{H}$, Sclerotinia sclerotiorum. All photographs were at $\times 400$ magnification. 
covered from the primary root, hypocotyl or lower stem, and secondary roots at 3,7 , and 17 days after planting, respectively, when these tissues developed. The rapid increase in population of ACM941 also was observed on these plant tissues, but not to the extent of that observed on the seed coat where the bioagent was applied. The maximum amount of ACM941 on a primary root was $3.9 \times 10^{5} \mathrm{CFU}$ and on a hypocotyl $1.6 \times 10^{5} \mathrm{CFU}$ observed at the final sampling time, 35 days after planting. The maximum amount on secondary roots was $5.5 \times 10^{5}$ CFU observed 28 days after planting. ACM941 was absent on nontreated seed and subsequent plant parts from the growth room.

Similar observations were made in the field experiments. The greatest population of ACM941 was found on the seed coat and at the third node stage of plant development (Table 2). A decreased population generally was observed for all plant parts from the third node to plant maturity, except on the hypocotyl at Burdick Farm, where the ACM941 population increased from $1.4 \times$ $10^{4} \mathrm{CFU}$ at the third node stage to $6.5 \times 10^{4} \mathrm{CFU}$ at maturity. ACM941 also was recovered in low frequency from all plant parts of nontreated seed at both field sites. The densities ranged from $<10$ to $1,700 \mathrm{CFU}$ and appeared not to be related to the plant parts and sampling times as observed for the treated seed.
Efficacy against seedborne fungal pathogens. ACM941 reduced the recovery of all fungal pathogens from the visibly poor seed (Table 3). Specifically, ACM941 reduced the recovery of Fusarium spp. by an average of $75 \%$ compared with the nontreated controls. This effect was significantly greater than that of thiram, which reduced the pathogen by only $2 \%$. Similarly, ACM941 reduced on average the recovery of A. alternata by $73 \%$, Ascochyta spp. by $84 \%, R$. solani by $100 \%$, and Rhizopus spp. by $71 \%$. These effects were greater than or equal to those of thiram, which reduced the respective pathogens by $74,40,69$, and $85 \%$.

ACM941 increased in vitro germination of the poor seed by $26 \%$ for AC Tamor and $61 \%$ for Radley (Table 3). These effects were significant compared with the nontreated controls, and greater than but not significantly different from those of thiram, which increased germination by 19 and $47 \%$ for the respective cultivars.

Seed treatment with ACM941 increased emergence and reduced root rot severity of plants grown from the visibly poor seed (Table 4). Compared with the nontreated controls, ACM941 increased emergence of AC Tamor by 11, 15, 25, 35, 15, and 15\%, and reduced root rot severity by $70,60,75,88,44$, and $78 \%$ after the treated seeds were stored for $1,3,7,14,28$, and 42 days,

TABLE 1. Density of CFU of ACM941 recovered from the rhizosphere of Radley field pea over a 35-day period after planting in vermiculite in the growth room

\begin{tabular}{lcccccc}
\hline & \multicolumn{5}{c}{ CFU $\times 1,000^{\mathrm{y}}$} \\
\cline { 2 - 6 } Plant part & 0 day $^{\mathrm{z}}$ & 3 days & 7 days & 17 days & 28 days \\
\hline Seed coat & $1.1 \pm 0.1$ & $4.6 \pm 0.5$ & $1,770.0 \pm 53.0$ & $4,183.3 \pm 507.9$ & $6,191.5 \pm 697.5$ & $11,008.3 \pm 1213.6$ \\
Primary root & $\ldots$ & $0.2 \pm 0.1$ & $170.7 \pm 23.9$ & $186.5 \pm 21.9$ & $131.1 \pm 48.3$ & $392.5 \pm 37.6$ \\
Hypocotyl or lower stem & & & & & & \\
$\quad(0$ to 3 cm above seed) & $\ldots$ & $\ldots$ & $4.9 \pm 4.4$ & $24.8 \pm 21.8$ & $76.4 \pm 70.1$ & $159.2 \pm 157.1$ \\
Secondary roots & $\ldots$ & $\ldots$ & $\ldots$ & $62.5 \pm 50.0$ & $551.0 \pm 288.0$ \\
\hline
\end{tabular}

y ... = Plant part was not developed or not found at the time of assessment.

z Control, seed was not planted.

TABLE 2. Density of CFU of ACM941 recovered from the rhizosphere of Profi field pea at two field sites near Morden, Manitoba in 2000

\begin{tabular}{|c|c|c|c|c|c|c|c|}
\hline \multirow[b]{3}{*}{ Plant part } & \multirow[b]{3}{*}{ Treatment } & \multicolumn{6}{|c|}{$\mathrm{CFU} \times 1,000^{\mathrm{y}}$} \\
\hline & & \multicolumn{3}{|c|}{ Morden Research Centre } & \multicolumn{3}{|c|}{ Burdick Farm } \\
\hline & & Third node & Early flowering & Maturity & Third node & Early flowering & Maturity \\
\hline \multirow[t]{2}{*}{ Seed coat } & Nontreated & $0.1 \mathrm{~b}$ & $0.9 \mathrm{~b}$ & $0.3 \mathrm{~b}$ & $0.0 \mathrm{~b}$ & $1.5 \mathrm{~b}$ & $0.7 \mathrm{~b}$ \\
\hline & ACM941 & $383.1 \mathrm{a}$ & $78.9 \mathrm{a}$ & $50.1 \mathrm{a}$ & $933.8 \mathrm{a}$ & $181.9 \mathrm{a}$ & $167.5 \mathrm{a}$ \\
\hline \multirow[t]{2}{*}{ Hypocotyl $^{\mathrm{z}}$} & Nontreated & $0.0 \mathrm{~b}$ & $0.8 \mathrm{~b}$ & $0.7 \mathrm{~b}$ & $0.0 \mathrm{~b}$ & $0.1 \mathrm{~b}$ & $0.2 \mathrm{~b}$ \\
\hline & ACM941 & $59.4 \mathrm{a}$ & $23.3 \mathrm{a}$ & $20.2 \mathrm{a}$ & $14.2 \mathrm{a}$ & $21.7 \mathrm{a}$ & $65.3 \mathrm{a}$ \\
\hline \multirow[t]{2}{*}{ Primary root } & Nontreated & $0.0 \mathrm{~b}$ & $0.8 \mathrm{~b}$ & $0.3 \mathrm{~b}$ & $0.0 \mathrm{~b}$ & $0.5 \mathrm{~b}$ & $0.5 \mathrm{~b}$ \\
\hline & ACM941 & $81.4 \mathrm{a}$ & $23.3 \mathrm{a}$ & $28.2 \mathrm{a}$ & $32.7 \mathrm{a}$ & $47.4 \mathrm{a}$ & $25.3 \mathrm{a}$ \\
\hline \multirow[t]{2}{*}{ Secondary roots } & Nontreated & $0.1 \mathrm{~b}$ & $1.7 \mathrm{~b}$ & $1.4 \mathrm{~b}$ & $0.3 \mathrm{~b}$ & $0.8 \mathrm{~b}$ & $1.2 \mathrm{~b}$ \\
\hline & ACM941 & $60.1 \mathrm{a}$ & $24.9 \mathrm{a}$ & $63.2 \mathrm{a}$ & $213.8 \mathrm{a}$ & $36.3 \mathrm{a}$ & $29.8 \mathrm{a}$ \\
\hline
\end{tabular}

y Hypocotyl or lower stem (0 to $3 \mathrm{~cm}$ above seed).

${ }^{\mathrm{z}}$ Data in a column under each plant part followed by the same letter are not significantly different at $P=0.05$ (LSD).

TABLE 3. Comparative evaluation of bioagent ACM941 and thiram seed treatments on the recovery of seedborne fungal pathogens and in vitro germination of field pea ${ }^{\mathrm{y}}$

\begin{tabular}{|c|c|c|c|c|c|c|}
\hline \multirow[b]{2}{*}{ Cultivar, treatment ${ }^{\mathrm{z}}$} & \multicolumn{5}{|c|}{ Recovery (\%) } & \multirow[b]{2}{*}{ In vitro germination $(\%)$} \\
\hline & Alternaria alternata & Ascochyta spp. & Fusarium spp. & Rhizoctonia solani & Rhizopus spp. & \\
\hline \multicolumn{7}{|l|}{ AC Tamor } \\
\hline Nontreated & $46.7 \mathrm{a}$ & $5.6 \mathrm{a}$ & $33.3 \mathrm{a}$ & $2.2 \mathrm{a}$ & $25.6 \mathrm{a}$ & $28.7 \mathrm{~b}$ \\
\hline Thiram & $11.1 \mathrm{~b}$ & $3.3 \mathrm{a}$ & $27.8 \mathrm{ab}$ & $0.0 \mathrm{a}$ & $7.8 \mathrm{~b}$ & $47.5 \mathrm{a}$ \\
\hline ACM941 & $1.1 \mathrm{c}$ & $0.0 \mathrm{a}$ & $10.0 \mathrm{~b}$ & $0.0 \mathrm{a}$ & $8.9 \mathrm{~b}$ & $55.0 \mathrm{a}$ \\
\hline \multicolumn{7}{|l|}{ Radley } \\
\hline Nontreated & $37.1 \mathrm{a}$ & $4.9 \mathrm{a}$ & $31.9 \mathrm{a}$ & $14.1 \mathrm{a}$ & $16.0 \mathrm{a}$ & $31.2 \mathrm{c}$ \\
\hline Thiram & $10.3 \mathrm{c}$ & $3.0 \mathrm{a}$ & $35.9 \mathrm{a}$ & $2.5 \mathrm{bc}$ & $5.1 \mathrm{~b}$ & $78.7 \mathrm{~b}$ \\
\hline ACM941 & $19.1 \mathrm{bc}$ & $1.6 \mathrm{a}$ & $6.7 \mathrm{~b}$ & $0.0 \mathrm{c}$ & $3.8 \mathrm{~b}$ & $92.5 \mathrm{a}$ \\
\hline
\end{tabular}

y Data in a column under each cultivar followed by the same letter are not significantly different at $P=0.05$ (LSD).

z Thiram at $75 \%$. 
respectively. Similarly, on Radley, ACM941 increased emergence by 35,15 , and $30 \%$, and reduced root rot severity by 91,100 , and $75 \%$ after being applied to the seed for 1, 3, and 14 days, respectively. The treatment effects were not significantly different among the six planting times within 42 days of storage for AC Tamor and three planting times within 14 days for Radley. Overall, ACM941 increased emergence by $22 \%$ and reduced root rot severity by $76 \%$. The effect was similar to thiram, which increased emergence by $29 \%$ and reduced root rot severity by $65 \%$.

Efficacy against soilborne fungal pathogens. Treatment of seeds with ACM941 increased emergence of pea seedlings by 26 , $38,27,12$, and $21 \%$, in soils infested with $F$. oxysporum f. sp. pisi, $F$. solani f. sp. pisi, $M$. pinodes, $R$. solani, and $S$. sclerotior-um, respectively, in the growth room (Table 5). These effects were similar to or less than those obtained with thiram and were significant for all pathogens. Although the bioagent appeared to reduce root rot severity to all the pathogens, the effect was statistically significant only for $F$. oxysporum f. sp. pisi and $S$. sclerotiorum. Thiram did not significantly reduce root rot severity associated with these pathogens.

In field experiments, disease severity was greater, emergence was lower, and treatment effects were greater in 1995 for both ACM941 and thiram than in 1996 and 1997 (Table 6). Seed treatment-cultivar interactions were not significant $(P<0.05)$ for any of the five pathogens. On average for the two cultivars, ACM941 increased emergence by 29, 50, 57, 17, and 36\%, respectively, for $F$. oxysporum f. sp. pisi, F. solani f. sp. pisi, $M$. pinodes, $R$. solani, and $S$. sclerotiorum. These effects were statistically significant for all pathogens and similar to those of thiram. The only significant differences in emergence between ACM941 and thiram treatments were for AC Tamor inoculated with $R$. solani and for Radley with $F$. solani f. sp. pisi, in which thiramtreated seeds gave significantly higher emergence. Yield data was not collected in 1995 due to the premature death of plants as a result of drought damage during the early growing season and flooding at maturity.

Seed treatment effects of ACM941 and those of thiram on the five pathogens were either insignificant or inconsistent in 1996 and 1997 (Table 6). Specifically, ACM941 increased emergence and yield significantly in both 1996 and 1997 against F. oxysporum f. sp. pisi, except for yield of Radley in 1996 and AC Tamor in 1997. Other significant effects observed were the emergence of Radley against S. sclerotiorum and emergence of both AC Tamor and Radley against F. solani f. sp. pisi and $R$. solani in 1997, yield of AC Tamor against M. pinodes in 1996, and yield of both cultivars against S. sclerotiorum in 1997. Significant treatment-cultivar interactions were not observed for these pathogens in either year. From 1995 to 1997, ACM941 increased emergence by $17,23,22,13$, and $18 \%$ and yield by 15 , 6, 28, 6, and $19 \%$ for F. oxysporum f. sp. pisi, F. solani f. sp. pisi, $M$. pinodes, $R$. solani, and $S$. sclerotiorum, respectively. These effects were similar to those achieved with thiram fungicide, which increased emergence by $22,26,23,13$, and $19 \%$, and yield by $5,2,18,-10$, and $6 \%$, for the respective pathogens.

\section{DISCUSSION}

C. rosea also has been reported as a biological control agent against different fungal plant pathogens, including Alternaria brassicicola (24), Bipolaris sorokiniana and F. culmorum (15),

TABLE 5. Comparative evaluation of bioagent ACM941 and thiram seed treatments for the control of five soilborne fungal pathogens on AC Tamor field pea in the growth room ${ }^{\mathrm{x}}$

\begin{tabular}{llcc}
\hline \multirow{2}{*}{ Pathogen $^{\mathrm{y}}$} & Treatment & $\begin{array}{c}\text { Emergence } \\
(\%)\end{array}$ & $\begin{array}{c}\text { Root rot } \\
\text { severity }(0-9)\end{array}$ \\
\hline Fusarium oxysporum f. sp. pisi & Thiram & $86.3 \mathrm{a}$ & $1.3 \mathrm{a}$ \\
& Nontreated & $21.9 \mathrm{c}$ & $2.6 \mathrm{a}$ \\
Fusarium solani f. sp. pisi & ACM941 & $47.5 \mathrm{~b}$ & $2.1 \mathrm{a}$ \\
& Nontreated & $23.1 \mathrm{~b}$ & $4.4 \mathrm{a}$ \\
& Thiram & $57.5 \mathrm{a}$ & $3.3 \mathrm{ab}$ \\
Mycosphaerella pinodes & ACM941 & $61.3 \mathrm{a}$ & $3.0 \mathrm{~b}$ \\
& Nontreated & $48.8 \mathrm{~b}$ & $3.2 \mathrm{a}$ \\
Rhizoctonia solani & Thiram & $67.5 \mathrm{a}$ & $2.3 \mathrm{a}$ \\
& ACM941 & $76.3 \mathrm{a}$ & $2.1 \mathrm{a}$ \\
\multirow{2}{*}{ Sclerotinia sclerotiorum } & Nontreated & $16.3 \mathrm{c}$ & $3.6 \mathrm{a}$ \\
& Thiram & $55.6 \mathrm{a}$ & $3.4 \mathrm{a}$ \\
& ACM941 & $28.8 \mathrm{~b}$ & $3.6 \mathrm{a}$ \\
& Nontreated & $24.4 \mathrm{c}$ & $3.8 \mathrm{a}$ \\
& Thiram & $68.1 \mathrm{a}$ & $3.2 \mathrm{ab}$ \\
& ACM941 & $45.6 \mathrm{~b}$ & $2.9 \mathrm{~b}$ \\
\hline
\end{tabular}

$\bar{x}$ Plants were grown in a soil mixture of 2:1:1 (vol/vol/vol) of loam soil, perlite, and peat moss. Data in a column under each pathogen followed by the same letter are not significantly different at $P=0.05$ (LSD).

${ }^{\mathrm{y}}$ Inoculum was prepared with autoclaved wheat grain and mixed at $5 \%$ (vol/vol) with the soil mixture.

z Thiram at $75 \%$.

TABLE 4. Comparative evaluation of bioagent ACM941 and thiram seed treatments on emergence and root rot severity of field pea in the growth room ${ }^{\mathrm{y}}$

\begin{tabular}{|c|c|c|c|c|c|}
\hline \multirow[b]{2}{*}{ Days after treatment } & \multirow[b]{2}{*}{ Treatment $^{\mathrm{Z}}$} & \multicolumn{2}{|c|}{ AC Tamor } & \multicolumn{2}{|c|}{ Radley } \\
\hline & & Emergence $(\%)$ & Root rot severity (0-9) & Emergence $(\%)$ & Root rot severity $(0-9)$ \\
\hline 1 & Nontreated & $69.9 \mathrm{~b}$ & $3.3 \mathrm{a}$ & $60.0 \mathrm{~b}$ & $1.1 \mathrm{a}$ \\
\hline \multirow[t]{3}{*}{3} & Nontreated & $65.0 \mathrm{~b}$ & $2.0 \mathrm{a}$ & $54.9 \mathrm{c}$ & $1.4 \mathrm{a}$ \\
\hline & Thiram & $90.9 \mathrm{a}$ & $1.4 \mathrm{ab}$ & $95.0 \mathrm{a}$ & $0.5 \mathrm{~b}$ \\
\hline & ACM941 & $80.0 \mathrm{a}$ & $0.8 \mathrm{~b}$ & $69.9 \mathrm{~b}$ & $0.0 \mathrm{~b}$ \\
\hline & ACM941 & $95.0 \mathrm{a}$ & $0.1 \mathrm{a}$ & $\ldots$ & $\ldots$ \\
\hline \multirow[t]{3}{*}{14} & Nontreated & $54.9 \mathrm{~b}$ & $0.8 \mathrm{a}$ & $54.9 \mathrm{~b}$ & $0.4 \mathrm{a}$ \\
\hline & Thiram & $95.0 \mathrm{a}$ & $0.1 \mathrm{~b}$ & $95.0 \mathrm{a}$ & $0.0 \mathrm{a}$ \\
\hline & ACM941 & $90.0 \mathrm{a}$ & $0.1 \mathrm{~b}$ & $84.9 \mathrm{a}$ & $0.1 \mathrm{a}$ \\
\hline \multirow[t]{3}{*}{28} & Nontreated & $75.0 \mathrm{~b}$ & $0.9 \mathrm{a}$ & $\ldots$ & $\ldots$ \\
\hline & Thiram & $94.8 \mathrm{a}$ & $0.2 \mathrm{a}$ & $\ldots$ & $\ldots$ \\
\hline & ACM941 & $90.0 \mathrm{a}$ & $0.5 \mathrm{a}$ & $\ldots$ & $\ldots$ \\
\hline
\end{tabular}

y Plants were grown in a soil mixture of 2:1:1 (vol/vol/vol) of loam soil, perlite, and peat moss. Data in a column under each seeding time followed by the same letter are not significantly different at $P=0.05$ (LSD); $\ldots=$ tests not conducted due to seed shortage.

z Thiram at $75 \%$. 
TABLE 6. Comparative evaluation of bioagent ACM941 and thiram seed treatments for the control of five soilborne fungal pathogens of field pea in the field at Morden, Manitoba from 1995 to $1997^{y}$

\begin{tabular}{|c|c|c|c|c|c|c|c|c|c|c|}
\hline \multirow[b]{3}{*}{ Pathogen, treatment ${ }^{\mathrm{z}}$} & \multicolumn{2}{|c|}{1995} & \multicolumn{4}{|c|}{1996} & \multicolumn{4}{|c|}{1997} \\
\hline & \multirow{2}{*}{$\begin{array}{c}\text { AC Tamor } \\
\begin{array}{c}\text { Emergence } \\
(\%)\end{array}\end{array}$} & \multirow{2}{*}{ 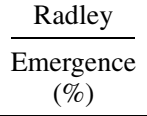 } & \multicolumn{2}{|c|}{ AC Tamor } & \multicolumn{2}{|c|}{ Radley } & \multicolumn{2}{|c|}{ AC Tamor } & \multicolumn{2}{|c|}{ Radley } \\
\hline & & & $\begin{array}{c}\text { Emergence } \\
(\%)\end{array}$ & $\begin{array}{l}\text { Yield } \\
\text { (kg/ha) }\end{array}$ & $\begin{array}{c}\text { Emergence } \\
(\%)\end{array}$ & $\begin{array}{l}\text { Yield } \\
(\mathrm{kg} / \mathrm{ha})\end{array}$ & $\begin{array}{c}\text { Emergence } \\
(\%)\end{array}$ & $\begin{array}{c}\text { Yield } \\
\text { (kg/ha) }\end{array}$ & $\begin{array}{c}\text { Emergence } \\
(\%)\end{array}$ & $\begin{array}{l}\text { Yield } \\
\text { (kg/ha) }\end{array}$ \\
\hline \multicolumn{11}{|c|}{ Fusarium oxysporum f. sp. pisi } \\
\hline Nontreated & $7.9 \mathrm{~b}$ & $28.5 \mathrm{~b}$ & $66.6 \mathrm{~b}$ & $5,232 \mathrm{a}$ & $79.1 \mathrm{~b}$ & $2,099 \mathrm{a}$ & $47.3 \mathrm{c}$ & 6,094 a & $55.3 \mathrm{~b}$ & $5,345 \mathrm{~b}$ \\
\hline Thiram & $45.4 \mathrm{a}$ & $57.1 \mathrm{a}$ & $78.3 \mathrm{a}$ & $5,203 \mathrm{a}$ & $85.9 \mathrm{ab}$ & $2,442 \mathrm{a}$ & $84.0 \mathrm{a}$ & $6,625 \mathrm{a}$ & $63.8 \mathrm{ab}$ & $5,037 \mathrm{~b}$ \\
\hline ACM941 & $43.4 \mathrm{a}$ & $50.3 \mathrm{a}$ & $72.0 \mathrm{ab}$ & 5,446 a & $89.1 \mathrm{a}$ & $3,050 \mathrm{a}$ & $57.2 \mathrm{~b}$ & 6,035 a & $76.7 \mathrm{a}$ & $6,037 \mathrm{a}$ \\
\hline Thiram & $64.1 \mathrm{a}$ & $82.5 \mathrm{a}$ & $76.1 \mathrm{a}$ & 5,374 a & $81.4 \mathrm{a}$ & $3,674 \mathrm{a}$ & $66.2 \mathrm{a}$ & 5,600 a & $65.7 \mathrm{~b}$ & $3,379 \mathrm{a}$ \\
\hline ACM941 & $67.5 \mathrm{a}$ & $62.3 \mathrm{~b}$ & $67.0 \mathrm{a}$ & $6,009 \mathrm{a}$ & $77.6 \mathrm{a}$ & $3,356 \mathrm{a}$ & $66.1 \mathrm{a}$ & $5,881 \mathrm{a}$ & $74.8 \mathrm{a}$ & $3,656 \mathrm{a}$ \\
\hline \multicolumn{11}{|c|}{ Mycosphaerella pinodes } \\
\hline Nontreated & $23.4 \mathrm{~b}$ & $28.4 \mathrm{~b}$ & $69.8 \mathrm{a}$ & $1,375 \mathrm{~b}$ & $70.6 \mathrm{~b}$ & $1,528 \mathrm{a}$ & $71.0 \mathrm{a}$ & $4,896 \mathrm{~b}$ & $73.4 \mathrm{a}$ & $3,456 \mathrm{a}$ \\
\hline Thiram & $75.0 \mathrm{a}$ & $79.5 \mathrm{a}$ & $76.3 \mathrm{a}$ & $2,140 \mathrm{ab}$ & $84.5 \mathrm{a}$ & $1,623 \mathrm{a}$ & $80.0 \mathrm{a}$ & 5,645 a & $80.2 \mathrm{a}$ & $3,328 \mathrm{a}$ \\
\hline ACM941 & $87.5 \mathrm{a}$ & $78.4 \mathrm{a}$ & $70.8 \mathrm{a}$ & $2,595 \mathrm{a}$ & $78.5 \mathrm{ab}$ & $1,661 \mathrm{a}$ & $72.1 \mathrm{a}$ & $5,201 \mathrm{ab}$ & $80.1 \mathrm{a}$ & $3,672 \mathrm{a}$ \\
\hline \multicolumn{11}{|l|}{ Rhizoctonia solani } \\
\hline Nontreated & $10.9 \mathrm{~b}$ & $38.1 \mathrm{~b}$ & $29.8 \mathrm{~b}$ & $4,225 \mathrm{a}$ & $34.3 \mathrm{~b}$ & 2,499 a & $37.1 \mathrm{a}$ & $5,227 \mathrm{~b}$ & $40.2 \mathrm{~b}$ & $4,398 \mathrm{~b}$ \\
\hline Thiram & $49.1 \mathrm{a}$ & $64.6 \mathrm{a}$ & $41.8 \mathrm{a}$ & $4,327 \mathrm{a}$ & $48.9 \mathrm{a}$ & $2,598 \mathrm{a}$ & $49.7 \mathrm{a}$ & $5,402 \mathrm{~b}$ & $50.5 \mathrm{a}$ & $5,049 \mathrm{a}$ \\
\hline ACM941 & $50.4 \mathrm{a}$ & $70.0 \mathrm{a}$ & $37.9 \mathrm{ab}$ & 4,989 a & $41.4 \mathrm{ab}$ & $2,954 \mathrm{a}$ & $41.8 \mathrm{a}$ & 6,640 a & $53.0 \mathrm{a}$ & $4,973 \mathrm{a}$ \\
\hline
\end{tabular}

${ }^{y}$ Data in a column under each pathogen followed by the same letter are not significantly different at $P=0.05$ (LSD).

${ }^{z}$ Thiram at $75 \%$.

Botrytis spp. (4,12,16,22,28,40), Phomopsis sclerotioides (17), and Verticillium dahliae (13). Several modes of antagonism of pathogens by $C$. rosea, including mycoparasitism, nutrient competition, and possibly induced resistance, have been suggested (28). Efforts to characterize the mycoparasitic action of ACM941 in the present study demonstrated that the bioagent did not form an inhibition zone in dual cultures with the eight PRRC pathogens tested. Observations of hyphal interactions between ACM941 and these pathogens revealed that the bioagent acted mainly by entwining and occasionally penetrating the pathogen hyphae (Fig. 1). These observations coincided with findings by Barnett and Lilly (3), who demonstrated that $C$. rosea was a mycoparasite, attacking and killing a wide range of fungi by entwining and hyphal penetration. It appeared that ACM941 destroyed the pathogen mycelia only after making physical contact, suggesting that the antagonistic capabilities of ACM941 were a result of such entwining and penetrating actions.

In addition to its direct antagonistic attack toward pathogens, ACM941 colonized the plant rhizosphere (Tables 1 and 2). ACM941 was recovered not only from the seed coat where it was applied, but also from the primary root, hypocotyl or lower stem, and secondary roots, indicating that the bioagent propagated in the soil on the surface and along plant tissues as they developed. The rapid increases of the ACM941 population observed on all of these plant parts indicate the potential of ACM941 to provide effective and long-lasting plant protection as a result of its application to the seed. The ability of ACM941 to survive and propagate within the rhizosphere is in contrast to chemical fungicides, which have a limited time span of effectiveness. It was unexpected but rather interesting to note that a low density of $C$. rosea was recovered from most plant parts of nontreated seeds in the field experiments. Such a finding was in agreement with early reports $(7,23)$ demonstrating that $C$. rosea is a naturally occurring and common soil fungus. The selective medium used does not differentiate $C$. rosea strains; therefore, it is not known whether the recovered $C$. rosea from the nontreated seed was ACM941 (e.g., contamination by the seeders) or other C. rosea strains in the soil, or a combination of both.

The observation that ACM941 applied to seed significantly reduced the recovery of PRRC pathogens and increased in vitro germination of visibly poor seed suggested that the bioagent has substantial potential to control many seedborne fungal pathogens involved in seed decay and root rot of field pea. This was substantiated in the growth room experiments using the same seed lots. Over the average of the six experiments, ACM941 increased emergence by $22 \%$ and reduced root rot severity by $76 \%$ (Table 4 ). These effects were not significantly reduced after the treated seed had been stored for 42 days, suggesting that the shelf life of ACM941 on seed could even be longer.

This study further demonstrated that ACM941 controls soilborne F. oxysporum f. sp. pisi, F. solani f. sp. pisi, M. pinodes, $R$. solani, and $S$. sclerotiorum in the growth room and field when used as a seed treatment. ACM941 increased emergence significantly for all five pathogens in the growth room (Table 5). Under field conditions, ACM941 increased both emergence and yield against these pathogens tested from 1995 to 1997 (Table 6). The effects were equal to or greater than those achieved with the commercial fungicide. These results suggest that ACM941 is an effective bioagent against PRRC pathogens when used as a seed treatment. Compared with the previously reported bioagents $(8-10,18$, 19,21,27,33,34), ACM941 displayed improved capabilities against the PRRC pathogens, prolonged the duration of protection, and broadened the range of pathogenic targets under various environmental conditions.

\section{ACKNOWLEDGMENTS}

I thank the Gustafson Partnership, the Agri-Food Research and Development Initiative, the Manitoba Pulse Growers Association, and the Alberta Pulse Growers Commission for financial support; H. Tuey, L. Yager, B. Dyck, I. Wolfe, F. Sabo, T. Potter, and Y. Chen for technical assistance; K. A. Seifert and C. Babcock for identifying some strains of C. rosea; and Y. K. Chen and M. Savard for advice on the manuscript.

\section{LITERATURE CITED}

1. Bailey, K. L., Mortensen, K., and Lafond, G. P. 1992. Effects of tillage systems and crop rotations on root and foliar disease of wheat, flax, and peas in Saskatchewan. Can. J. Plant Sci. 72:583-591.

2. Baker, R., and Paulitz, T. C. 1996. Theoretical basis for microbial interactions leading to biological control of soilborne plant pathogens. Pages 
50-79 in: Principles and Practice of Managing Soilborne Plant Pathogens. R. Hall, ed. The American Phytopathological Society, St. Paul, MN.

3. Barnett, H. L., and Lilly, V. G. 1962. A destructive mycoparasite, Gliocladium roseum. Mycologia 54:72-77.

4. Burgess, D. R., Bretag, T., and Keane, P. J. 1997. Biocontrol of seedborne Botrytis cinerea in chickpea with Gliocladium roseum. Plant Pathol. 46:298-305.

5. Cody, R. P., and Smith, J. K. 1991. Applied Statistics and SAS Programming Language, 3rd ed. SAS Institute Inc., Cary, NC.

6. Cook, R. J., and Baker, K. F. 1983. The Nature and Practice of Biological Control of Plant Pathogens. The American Phytopathological Society, St. Paul, MN.

7. Domsch, K. H., Gams, W., and Anderson, T.-H. 1980. Compendium of Soil Fungi. Academic Press, London.

8. Harman, G. E., Chet, I., and Baker, R. 1980. Trichoderma hamatum effects on seed and seedling disease induced in radish and pea by Pythium spp. or Rhizoctonia solani. Phytopathology 70:1167-1172.

9. Hwang, S. F., and Chakravarty, P. 1992. Potential for the integrated control of Rhizoctonia root rot of Pisum sativum using Bacillus subtilis and a fungicide. J. Plant Dis. Prot. 99:626-636.

10. Hwang, S. F., and Chakravarty, P. 1993. Integrated biological and chemical control of Rhizoctonia root rot of field pea by Gliocladium virens and a fungicide. J. Plant Dis. Prot. 100:308-316.

11. Hwang, S. F., Lopertinsky, K., and Evans, I. R. 1991. Effects of seed infection by Ascochyta spp., fungicide seed treatment, and cultivar on yield parameters of field pea under field conditions. Can. Plant Dis. Surv. 71:169-172.

12. James, T. D. W., and Sutton, J. C. 1996. Biological control of Botrytis leaf blight of onion by Gliocladium roseum applied as sprays and with fabric applicators. Eur. J. Plant Pathol. 102:265-275.

13. Keinath, A. P., Fravel, D. R., and Papavizas, G. C. 1991. Potential of Gliocladium roseum for biocontrol of Verticillium dahliae. Phytopathology 81:644-648.

14. Kirkham, C. 1992. Pea diseases in N.E. Saskatchewan, 1991. Can. Plant Dis. Surv. 72:87.

15. Knudsen, I. M. B., Hockenhull, J., and Jensen, D. F. 1995. Biocontrol of seedling diseases of barley and wheat caused by Fusarium culmorum and Bipolaris sorokiniana: effects of selected fungal antagonists on growth and yield components. Plant Pathol. 44:467-477.

16. Köhl, J., Molhoek, W. M. L., Van der plas, C. H., and Fokkema, N. J. 1995. Suppression of sporulation of Botrytis spp. as a valid biocontrol strategy. Eur. J. Plant Pathol. 101:251-259.

17. Moody, A. R., and Gindrat, D. 1977. Biological control of cucumber black root rot by Gliocladium roseum. Phytopathology 67: 1159-1162.

18. Nelson, E. B., Harman, G. E., and Nash, G. T. 1988. Enhancement of Trichoderma-induced biological control of Pythium seed rot and preemergence damping-off of peas. Soil Bio. Biochem. 20:145-150.

19. Oyarzun, P. J., Postma, J., Luttikholt, A. J. G., and Hoogland, A. E. 1994. Biological control of foot and root rot in pea caused by Fusarium solani with nonpathogenic Fusarium oxysporum isolates. Can. J. Bot. 72:843852 .

20. Park, Y. H., Stack, J. P., and Kenerley, C. M. 1992. Selective isolation and enumeration of Gliocladium virens and G. roseum from soil. Plant Dis. 76:230-235.
21. Parke, J. L., Rand, R. E., Joy, A. E., and King, A. E. 1991. Biological control of Pythium damping-off and Aphanomyces root rot of peas by application of Pseudomonas cepacia or P. fluorescens to seed. Plant Dis. 75:987-992.

22. Pennock-Vos, M. G., Roebroeck, E. J. A., and Skrzypczak, C. 1990. Preliminary results on biological control of Botrytis cinerea in forced tulips. Acta Hortic. 266:425-428.

23. Pugh, G. J. F., and Dickinson, C. H. 1965. Studies on fungi in coastal soils. VI. Gliocladium roseum Bainier. Trans. Br. Mycol. Soc. 48:279285.

24. Sivapalan, A. 1993. Fungi associated with broccoli seed and evaluation of fungal antagonists and fungicides for the control of seed-borne Alternaria brassicicola. Seed Sci. Technol. 21:237-245.

25. Slinkard, A. E., Bascur, G., and Hernandez-Bravo, G. 1994. Biotic and abiotic stresses of cool season food legumes in the western hemisphere. Pages 195-203 in: Expanding the Production and Use of Cool Season Food Legumes. F. J. Murhlbauer and W. J. Kaiser, eds. Kluwer Academic Publishers, The Netherlands.

26. Statistics Canada. 2000. Field crop reporting series no. 7. Catalogue No. 22-002-XPB Vol. 79, No. 7.

27. Steinmetz, J., and Schonbeck, F. 1994. Conifer bark as growth medium and carrier for Trichoderma harzianum and Gliocladium roseum to control Pythium ultimum on pea. Z. Pflanzenkrankh. Pflanzenschutz. 101:200-211.

28. Sutton, J. C., Li, D. W., Peng, G., Yu, H., Zhang, P. G., and ValdebenitoSanhueza, R. M. 1997. Gliocladium roseum: A versatile adversary of Botrytis cinerea in crops. Plant Dis. 81:316-328.

29. Tu, J. C. 1986. Incidence and etiology of pea rots in southwestern Ontario. Can. Plant. Dis. Surv. 66:35-36.

30. Tu, J. C. 1987. Integrated control of the pea root rot disease complex in Ontario. Plant Dis. 71:9-13.

31. Tu, J. C. 1991. Etiology, biology and control of a soilborne root rot complex of green peas. Plant Prot. Bull. 33:15-35.

32. Tu, J. C. 1992. Management of root rot diseases of peas, beans, and tomatoes. Can. J. Plant Pathol. 14:92-99.

33. Windels, C. E., and Kommedahl, T. 1978. Factors affecting Penicillium oxalicum as a seed protectant against seedling blight of pea. Phytopathology 68:1656-1661.

34. Xi, K., Stephens, J. H. G., and Verma, P. R. 1996. Application of formulated rhizobacteria against root rot of field pea. Plant Pathol. 45:11501158.

35. Xue, A. G. 1998. Gliocladium roseum strains useful for the control of fungal pathogens in plants. U.S. patent 60/102,582.

36. Xue, A. G. 2000. Effect of seedborne Mycosphaerella pinodes and seed treatments on emergence, foot rot severity and yield of field pea. Can. J. Plant Pathol. 22:248-253.

37. Xue, A. G. 2001. Biological control of root rots in field pea. Can. J. Plant Pathol. 23:209.

38. Xue, A. G., and Burnett, P. A. 1994. Diseases of field pea in central Alberta in 1993. Can. Plant Dis. Surv. 74:102-103.

39. Xue, A. G., Tuey, H. J., and Platford, R. G. 2000. Diseases of field pea in Manitoba in 1999. Can. Plant Dis. Surv. 80:110-111.

40. Zhang, P. G., Sutton, J. C., Tan, W., and Hopkin, A. A. 1996. Gliocladium roseum reduces physiological changes associated with infection of black spruce seedlings by Botrytis cinerea. Can. J. Plant Pathol. 18:7-13. 